\title{
Impact of Global Trends on Hotel Business in Bratislava City
}

\author{
Anna Veszprémi Sirotková \\ University of Economics in Bratislava, Bratislava, Slovakia
}

\begin{abstract}
Hotel business is very competitive and this is the reason of strong efforts of hotel keepers to follow and implement the latest technology, product, and marketing trends into their own business. The aim of the article is to point out the new global trends in hotel business and to show how they impact the hotel business in Bratislava. Bratislava, as the capital of Slovakia, is known as the favorite tourist and business travel destination with several global luxury brand hotels established here. The results were achieved through primary and secondary research. Our results and conclusions show that global trends in hotel business positively influence the quality and performance of hotels in Bratislava.
\end{abstract}

Keywords: hotel business, global trends, technology, marketing

\section{Introduction}

Endeavour of product quality improvement and cost reduction leads hotels to seek their ways to solve these problems also through the way of cooperation with the other enterprises in the form of informal and formal agreements, which bring advantages to all participated parties. In this case, we talk about integration groupings, alliances, and networks. Hotels seek ways to improve their performance by innovations in product, processes, management, and marketing. There are many internet sources where they can find information on the latest trends in technology, new products, and services, for example, Hospitality Upgrade, Hotels-online, Hotelsmag.com, etc.. They may join discussion groups on LinkedIn, for example: Top Hotel Projects; International Luxury Hotel Association: Hospitality, Hotels, Travel, Food, Beverage, Tourism, Brand Management, etc.. In the next part, we will show some findings on the latest trends in hotel industry and how they impact the hotel business in Bratislava.

\section{Literature Review}

Main driving forces in global economy are considered IT technologies, mobility of people, and tourism, in frame of which hotel businesses as providers of accommodation services play a significant role. Hotels are accommodation facilities for temporary accommodation of guests, which have more than 10 rooms. They offer, except accommodation and catering, also complementary services, entertainment and social services, services to business travellers, and recreation and sport services for active spending of free time (Novacká, Magátová, Bartoš, Benčič, Ivanović, Kubíčková, ..., \& Trefil, 2010).

Hotels offer services not only for visitors, but also for local residents. They contribute conditions for sustainable development with multiplicative effects on national economy rebound mostly in revenues of business in tourism and supply sector, in income from contributions and taxes to state budget, and in employment rate increase, particularly of young and less qualified people.

Anna Veszprémi Sirotková, senior assistant, Department of Services and Tourism, University of Economics in Bratislava. Email: anna.sirotkova@euba.sk. 
Product of hotels was defined by several authors (Kotler, 2005; Novacká et al., 2010; Gúčik, 2007; Hollensen, 2011; Horner \& Swarbrooke, 2003; Walker, 2002). As it consists of accommodation, hospitality, and complementary services, has intangible features such as experience of the guest, and is impossible to store it, it is very important to sell as many rooms as possible through several distribution channels with strong marketing efforts based on excellent product for an appropriate price.

Economic sphere has significantly changed thanks to technology and globalization. Consumers are more educated and have better tools, e.g., the internet, which allows them to have a better choice when buying (Kotler, 2005). These trends appear also in hotel business, where permanent innovations are necessary (Orieška \& Smutná, 2013). Main ways of building the competition advantage are product improvement and creation of the long-term relationships with customers (Lesáková, 2006).

It is not possible to try the product of hotel in advance and the purchase of this product always represents a certain risk for the customer. From this reason, it is very important for the hotel to gain the customers' confidence. This confidence is empowered by good reputation of the hotel with top-quality services at favourable prices.

In the past, information about hotel was widened mostly by verbal communication. In recent time, internet social networks, such as Twitter and Facebook, allow sharing information much faster to significantly more people. This means a high potential risk according to the fact that unsatisfied customers share their negative experience much more often than the satisfied one. There are some specialized internet portals where people can share their experience in hotels and may also make a reservation of the hotel room, such as Booking.com, Trip Advisor, Expedia, etc..

These global trends influence also hotel business in Slovakia, small country in Central Europe, with about 5.4 million inhabitants and over 3,000 accommodation facilities including 632 hotels, motels, and boatels (Ministry of Transportation, Construction, and Regional Development of the Slovak Republic, 2015).

Performance of tourism accommodation establishments is in the centre of interest of many authors. Novacká and Kočan (2014) focused on destination management, sustainable development, destination branding, and consumer behaviour of foreign guests and closely cooperate with Bratislava Tourist Board. Gúčik and Uličná (2014) dealt with the establishment of chain hotels in Slovakia. Orieška and Smutná (2013) oriented their research to innovation of hotel accommodation services in the Slovak Republic. Malachovský (2013) has published the analysis of development of hotel market in Bratislava in the period of 2001-2011. Plesník (2008) and Michálková (2010) examined the definition and valuation of regions and regional networks in tourism. Lee, Reid, and Kim (2012) explored the nature of knowledge sharing in online travel communities. Anderson (2012) has published the results of his research of the impact of social media on lodging performance. Rauch (2014) and Sanghi (2014) defined global trends impacting the hospitality industry. These researchers inspired the author of this paper to aim this research to examine the impact of global trends on hotel business in Bratislava city, as the capital of Slovakia, based on latest available data.

\section{Methodology}

This paper aims to point out the new global trends in hotel business and to show how they impact the hotel business in Bratislava. Bratislava is the capital city of Slovakia and is known as the favorite tourist and business travel destination with several global luxury brand hotels established here. 
The results were defined through primary and secondary research by using several statistics and graphic methods. We have completed firstly literary research of the latest articles of authors in Slovakia and in other countries to gain the complete point of view on the selected theme. We have analyzed 38 top luxury hotels in Bratislava as we consider them being leaders in technology innovations.

We have compared branded and independent hotels. Our results and conclusions show that global trends in hotel business positively come from branded hotels. Strong competition in saturated market, on one hand, positively influences the quality and performance of hotels in Bratislava, but on the other hand, it leads to a decrease in prices for accommodation services and to lower occupancy rate.

\section{Global Trends in Hotel Industry for 2014}

Hotel business faces many positive and negative trends and also externalities from an external environment, both local and global. It is crucial for their survival to know them and react in the best possible way. Many consulting companies (PwC, STR Global) and research institutions (Cornell University, University of Economics in Bratislava) base their interest on the observation of new trends in tourism, hotel, and hospitality industry.

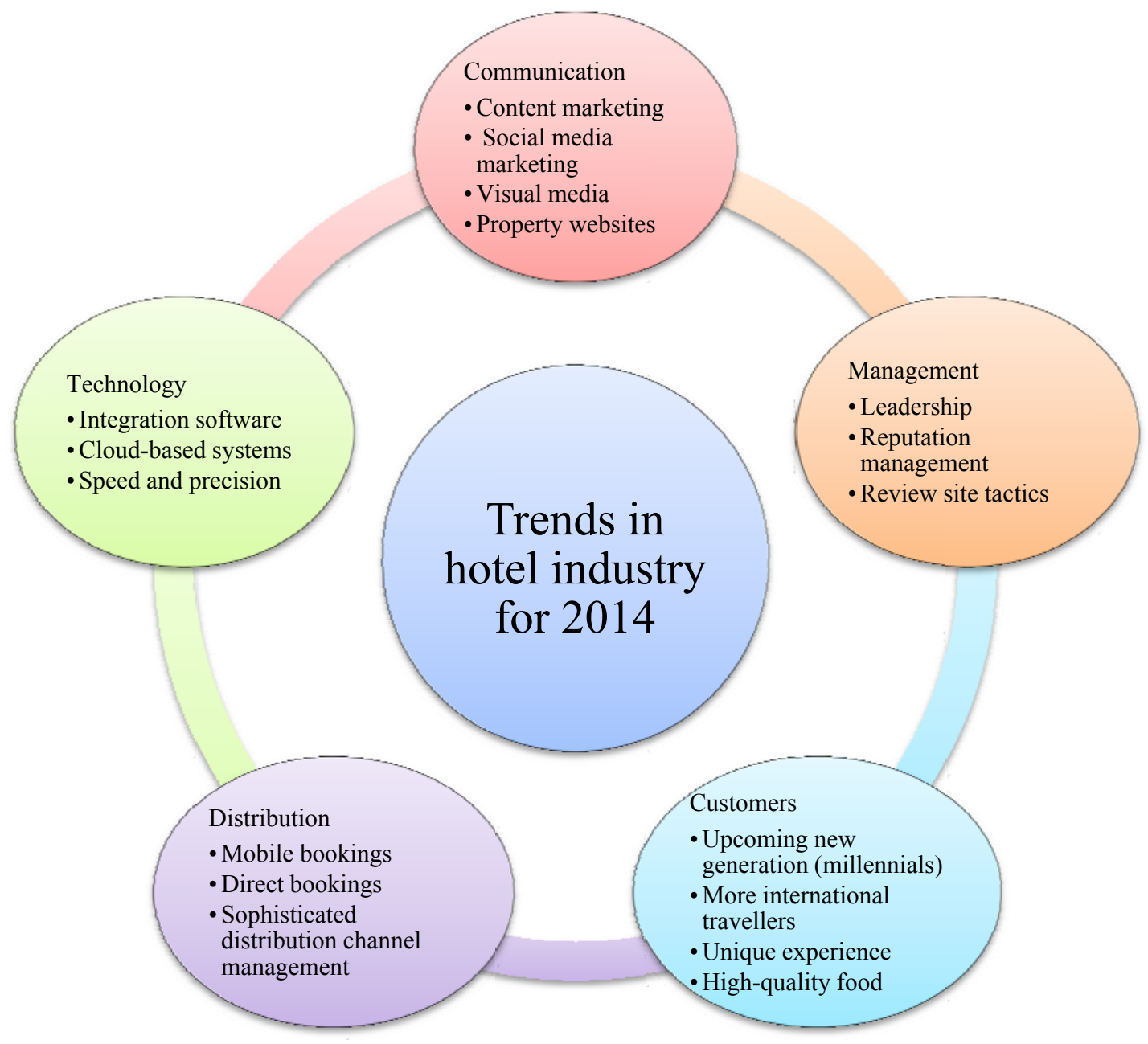

Figure 1. Global trends in hotel industry for 2014. Source: Rauch (2014) and Sanghi (2014). 
We were inspired by Rauch (2014) and Sanghi (2014) in creating the figure of global trends in hotel industry for 2014 (see Figure 1).

Customers of hotels are sophisticated and they have an access to gain all information they need when selecting the hotel of their choice. Their uncertainty is lower when they find reviews of hotels put by their friends and family members on internet travel pages such as Yelp, Booking.com, Trip Advisor, Expedia, etc.. It is very important for hotel management to review these sites too to be informed about the reactions of their guests and the guests' experience with the services they provide. New technologies also help managers to save their time and money.

\section{Actual Performance of Accommodation Facilities in Bratislava and in Slovakia Regions}

In this part, we would like to compare Bratislava with the rest regions in Slovakia, with the purpose to point out that this location has big advantages due to its excellent cultural, political, economic, and social environment with many attractions and events for both tourists and business travellers. These advantages lead to better results in hotels' performance. In past years, this leaded to huge investment in hotel business in luxury hotels segment by strong international hotel companies with branded hotels, and some Slovak investors have established their new independent luxury hotels. Due to crisis, the hotel market became saturated and it caused a decrease in the actual number of hotel facilities in comparison with the last year. The comparison of Bratislava and other regions in Slovakia is shown in Table 1.

Table 1

The Capacity and Performance of Accommodation Facilities in Slovakia Regions in 2014/2013

\begin{tabular}{|c|c|c|c|c|c|c|c|c|}
\hline \multirow{2}{*}{ Region } & \multicolumn{2}{|c|}{$\begin{array}{c}\text { Number of } \\
\text { accommodation facilities }\end{array}$} & \multicolumn{2}{|c|}{ Number of rooms } & \multicolumn{2}{|c|}{ Number of beds in total } & \multicolumn{2}{|c|}{ Bed occupancy (\%) } \\
\hline & 2013 & 2014 & 2013 & 2014 & 2013 & 2014 & 2013 & 2014 \\
\hline Bratislava & 233 & 221 & 10,206 & 9,724 & 22,681 & 21,466 & 26.7 & 26.3 \\
\hline Trnava & 276 & 265 & 5,861 & 5,674 & 13,826 & 13,286 & 23.6 & 28.0 \\
\hline Trenčín & 246 & 234 & 4,781 & 4,903 & 11,377 & 11,471 & 23.0 & 28.7 \\
\hline Nitra & 307 & 292 & 5,064 & 5,105 & 13,014 & 13,130 & 17.0 & 19.7 \\
\hline Žilina & 882 & 839 & 12,442 & 11,933 & 34,690 & 33,655 & 21.4 & 23.4 \\
\hline Banská Bystrica & 494 & 475 & 7,520 & 7,368 & 19,731 & 19,332 & 24.4 & 26.7 \\
\hline Prešov & 701 & 663 & 11,239 & 11,004 & 30,241 & 29,428 & 26.8 & 28.5 \\
\hline Košice & 346 & 329 & 5,465 & 5,393 & 14,297 & 14,285 & 11.0 & 13.3 \\
\hline Total & 3,485 & 3,318 & 62,578 & 61,104 & 159,857 & 156,053 & 22.3 & 24.8 \\
\hline
\end{tabular}

Note. Source: Ministry of Transportation, Construction, and Regional Development of the Slovak Republic (2015).

From Table 1, we may see the decrease in capacity and occupancy in Bratislava region in the first quarter of 2014 in comparison with that of the same period in 2013. The largest capacity of accommodation facilities is in Žilina region, and the highest occupancy rate was reached in Trenčín region, where most famous Slovakia spas are located. When comparing the number of accommodation facilities and the number of beds, we may conclude that although Bratislava region has only 221 accommodation facilities, their capacity in the numbers of rooms and beds is comparable with the top regions in Slovakia.

The performance of accommodation establishments in Slovakia regions in 2014 and its comparison to year 2013 is shown in Table 2. Despite that the year 2013 was very successful, the decrease in the performance of accommodation establishments is very significant and hotels face the need to increase their effort to attract more guests. 
Table 2

Performances of Tourism Accommodation Establishments in Slovakia in 2014/2013

\begin{tabular}{|c|c|c|c|c|c|c|c|}
\hline \multirow[t]{2}{*}{ Region } & \multicolumn{2}{|c|}{$\begin{array}{c}\text { Turnover from accommodation } \\
\text { services to all visitors } \\
\text { (EUR) }\end{array}$} & \multicolumn{2}{|c|}{$\begin{array}{c}\text { Turnover from accommodation } \\
\text { services to foreign visitors } \\
\text { (EUR) }\end{array}$} & \multirow{2}{*}{$\begin{array}{l}\text { The share of } \\
\text { visitors on total } \\
\text { turnover }(\%)\end{array}$} & \multicolumn{2}{|c|}{$\begin{array}{c}\text { Average price for } \\
\text { accommodation } \\
\text { services (EUR) }\end{array}$} \\
\hline & 2014 & Index 14/13 & 2014 & Index 14/13 & & 2013 & 2014 \\
\hline Bratislava & $62,565,558$ & 80.6 & $56,041,970$ & 77.2 & 69.1 & 35.6 & 30.9 \\
\hline Trnava & $26,818,075$ & 104.5 & $15,554,252$ & 104.9 & 60.8 & 23.8 & 24.1 \\
\hline Trenčín & $24,718,103$ & 103.2 & $6,842,860$ & 98.2 & 27.2 & 24.6 & 25.0 \\
\hline Nitra & $16,232,220$ & 102.3 & $7,879,993$ & 93.2 & 45.2 & 25.9 & 24.7 \\
\hline Žilina & $50,343,431$ & 92.4 & $22,055,847$ & 89.1 & 39.0 & 22.7 & 23.4 \\
\hline Banská Bystrica & $28,649,028$ & 100.1 & $6,363,527$ & 86.3 & 19.1 & 21.4 & 22.2 \\
\hline Prešov & $44,559,902$ & 96.4 & $18,298,542$ & 89.0 & 36.5 & 20.5 & 20.8 \\
\hline Košice & $13,663,968$ & 84.0 & $7,412,043$ & 82.5 & 44.8 & 25.0 & 25.4 \\
\hline Total & $267,550,285$ & 92.7 & $140,445,034$ & 86.3 & 45.3 & 25.1 & 24.5 \\
\hline
\end{tabular}

Note. Source: Ministry of Transportation, Construction, and Regional Development of the Slovak Republic (2015) and own caculations.

Bratislava region in this period had the highest turnover for accommodation services to all visitors and the highest turnover for accommodation services to foreign visitors, despite the fact that it reached the worst decrease in turnover from accommodation services by $19.4 \%$ in total turnover for accommodation services and by $22.8 \%$ in turnover for accommodation services to foreign visitors. Decrease in the average price for accommodation services was $13.2 \%$. On the other side, Bratislava has the highest share of foreign visitors on total turnover and also the highest average price for accommodation services. The latest possible data on visitors and nights spent in Bratislava are given by Bratislava Tourist Board, which pointed out that most visitors come to Bratislava during July and August (Bratislava Tourist Board, 2014a; 2014b). Results in performance of accommodation services in Bratislava in 2014 demonstrate how sensitive a hotel market in Bratislava is.

\section{Overview of Evaluation of Bratislava Luxury Hotels by Visitors on Selected Internet Travel Portals}

Luxury hotels are expected to offer their guests the most memorable experience. To sustain their position on the market due to strong competition and limited demand, they improve their products according to latest trends. They try to achieve better performance results by reducing the costs by applying new technologies in processes, management, and also marketing. Branded hotels mostly use the same technologies as their hotel company to sustain the compatibility of all hotel property management systems (PMS). Independent hotels have to keep their competitiveness by offering original top-quality products and implementing all possible innovations in all their activities.

All luxury hotels in Bratislava have an access to internet, email, and internet reservation systems. It is a necessity due to the fact that internet purchases have a fast growing trend. It is visible in Table 3 , where we can see its development in selected European countries since 2004. In 2014 in Slovakia, 31\% of all purchases were realized via the internet.

Hotels in Slovakia may purchase modern PMS also from domestic suppliers, for example, Asseco Solutions or ALTO Slovakia, which actualize them according to all legislative changes. Modern marketing tools, such as cloud solutions, mobile applications, and social marketing, are also affordable for them. Hotels 
may see feedback from their guests on several internet travel portals. It is very important for them to react on both positive and negative comments to insure that they care about their guests and that the satisfaction of their needs is a priority for them. In our research, we observed an evaluation of all medium and luxury hotels in Bratislava by travelers on internet traveler portals like Booking.com and TripAdvisor.com. The results are given in Table 4.

Table 3

Internet Purchases by Individuals (\%)

\begin{tabular}{lclll}
\hline Geo/year & 2004 & 2011 & 2013 & 2014 \\
\hline European Union (28 countries) & NA & 33 & 38 & 41 \\
Czech Republic & 3 & 16 & 21 & 25 \\
Germany (until 1990 former territory of the FRG) & 29 & 54 & 60 & 61 \\
Hungary & 2 & 13 & 17 & 20 \\
Austria & 13 & 35 & 46 & 43 \\
Poland & 3 & 20 & 23 & 24 \\
Slovakia & 6 & 23 & 30 & 31 \\
\hline
\end{tabular}

Note. Source: Eurostat (2015).

Table 4

Overview of Evaluation of Bratislava Medium and Luxury Hotels by Visitors on Selected Internet Travel Portals

\begin{tabular}{lcllll}
\hline \multirow{2}{*}{ Hotel class } & \multicolumn{3}{c}{ Booking.com } & & \multicolumn{2}{c}{ TripAdvisor.com } \\
\cline { 2 - 3 } \cline { 5 - 6 } & No. of evaluations & Average evaluation & & No. of evaluations & Average evaluation \\
\hline 3-star & 6,203 & 7.8 & 1,607 & 6.5 \\
4-star & 15,394 & 8.588 & 4,661 & 8.2 \\
5-star & 1,978 & 9.34 & 1,976 & 9.6 \\
\hline
\end{tabular}

Note. Source: Processed and calculated data of individual hotels on internet sites of Booking.com and TripAdvisor.com. Retrieved from http://www.booking.com and http://www.tripadvisor.com.

Hotels could gain maximum 10 points. We can see that the top results were reached by top luxury hotels, and four from five of the 5-star hotels were internationally branded. In luxury segment of 4- and 5-star hotels, there were 13 internationally branded hotels in the top 20. Based on the research result, we may confirm that internationally branded hotels in Bratislava are considered of higher quality and higher satisfaction of guests and they are leaders in all spheres of hotel business.

\section{Conclusion}

The aim of the article was to point out the new global trends in hotel business and to show how they impact the hotel business in Bratislava. Bratislava, as the capital city of Slovakia, is known as the favorite tourist and business travel destination with several global luxury brand hotels established here.

According to the research result, we may confirm that internationally branded hotels in Bratislava implement and follow the global trends in hotel industry and as a result, they perform higher-quality services and gain a higher satisfaction of guests. Independent hotels in this very competitive environment have to keep up with them in terms of performance of high-quality services and high satisfaction of their guests by following the global trends in hotel business. It may be seen in the economic results of this region. 
Bratislava region had, in 2014, the highest turnover for accommodation services to all visitors and the highest turnover for accommodation services to foreign visitors among all other much larger regions in Slovakia. Bratislava has the highest share of foreign visitors on total turnover and also the highest average price for accommodation services.

\section{References}

Anderson, C. (2012). The impact of social media on lodging performance. Cornell Hospitality Report, Vol. 12 No. 15, Cornell University School of Hotel Administration.

Bratislava Tourist $\quad$ Board. (2014a). Analýzy a štatistiky. Retrieved from

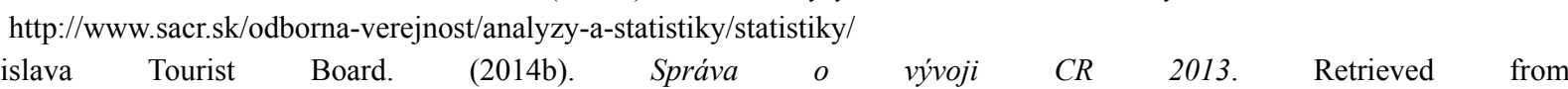

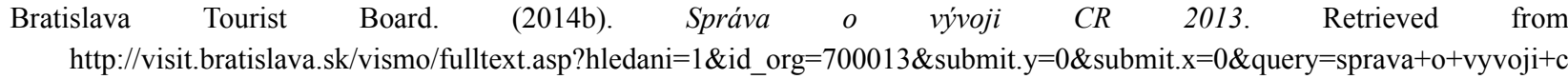
estovneho+ruchu+za+rok $+2013 \&$ submit. $=0 \&$ submit. $=0$

Eurostat. (2015). Internet purchases by individuals. $\quad$ Retrieved from http://appsso.eurostat.ec.europa.eu/nui/show.do?dataset=isoc_ec_ibuy\&lang=en

Gúčik, M. (2007). Hotel - ret’az služieb a súbor zážitkov. In Top Hotelierstvo. Žilina: MEDIA/ST, s.r.o.

Gúčik, M., \& Uličná, K. (2014). Etablovanie siel’ových hotelov na Slovensku (The establishment of Chain hotels in Slovakia). In Ekonomická revue cestovného ruchu, 47(2), 68-78.

Hollensen, S. (2011). Global marketing: A decision-oriented approach (5th ed.). Harlow: Prentice Hall Pearson Education Limited.

Horner, S., \& Swarbrooke, J. (2003). Cestovní ruch, ubytování a stravování, využití volného času. Praha: Grada Publishing.

Kotler, P. (2005). Marketing v otázkách a odpovědich. Brno: CP Books.

Lee, H., Reid, E., \& Kim, W. G. (2012). Understanding knowledge sharing in online travel communities: Antecedents and the moderating effects of interaction modes. Journal of Hospitality and Tourism Research, 38(2), 222-242.

Lesáková, D. (2006). Determinanty a miery marketingovej úspešnosti v stratégiách konkurencieschopnosti v ére nového marketingu. Bratislava: EKONÓM.

Malachovský, A. (2013). Analýza hotelového trhu v Bratislave (Bratislava Hotel Market Analysis). In Ekonomická revue cestovného ruchu, 46(3), 132-140.

Michálková, A. (2010). Regionálne siete v cestovnom ruchu. Bratislava: EKONÓM.

Ministry of Transportation, Construction, and Regional Development of the Slovak Republic. (2015). Capacity and performances of tourism accommodation establishments in Slovakia in 2014/2013 - by regions. Retrieved from http://www.telecom.gov.sk/index/index.php?ids=159243\&lang=en

Novacká, L., \& Kočan, R. (2014). Marketingová stratégia destinácie Bratislavský región doma i v zahraničí pre roky $2014-2016$ s výhl'adom do roku $2020 \quad$ (1st ed.). Bratislava: GFK Slovakia. Retrieved from http://www.region-bsk.sk/strategia-rozvoja-cestovneho-ruchu.aspx

Novacká, L., Magátová, M., Bartoš, L., Benčič, S., Ivanović, V., Kubíčková, D., ..., \& Trefill, P. (2010). Cestovný ruch, technika služieb, delegát a sprievodca. Bratislava: EKONÓM.

Orieška, J., \& Smutná, E. (2013). Inovácie služieb ubytovacích zariadení hotelového typu v Slovenskej republike. In Ekonomická revue cestovného ruchu (pp. 4-14).

Plesník, P. (2008). Vymedzenie a ocenenie regiónov cestovného ruchu. Bratislava: EKONÓM.

Rauch, R. (2014). Top 10 hospitality industry trends in 2014. Retrieved from http://www.hospitalitynet.org/news/4063217.html

Sanghi, M. (2014). Top 10 hotel hospitality industry latest trends of 2014 . Retrieved from http://www.hotelogix.com/blog/2014/01/07/top-10-hotel-hospitality-industry-upcoming-trends-of-2014/

Walker, J. R. (2002). Introduction to hospitality. London, UK: Prentice Hall International Limited. 